\title{
Turn Anger into Passionate Disagreement?
}

A Pragmatic Proposal

\section{Mara-Daria Cojocaru}

\section{OpenEdition}

\section{Journals}

Electronic version

URL: http://journals.openedition.org/ejpap/2147

DOI: $10.4000 /$ ejpap.2147

ISSN: 2036-4091

\section{Publisher}

Associazione Pragma

\section{Electronic reference}

Mara-Daria Cojocaru, «Turn Anger into Passionate Disagreement? », European Journal of Pragmatism and American Philosophy [Online], XII-2 | 2020, Online since 14 December 2020, connection on 15 December 2020. URL : http://journals.openedition.org/ejpap/2147 ; DOI : https://doi.org/10.4000/ ejpap.2147

This text was automatically generated on 15 December 2020.

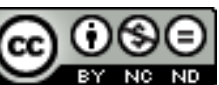

Author retains copyright and grants the European Journal of Pragmatism and American Philosophy right of first publication with the work simultaneously licensed under a Creative Commons AttributionNonCommercial-NoDerivatives 4.0 International License. 


\section{Turn Anger into Passionate Disagreement?}

A Pragmatic Proposal

Mara-Daria Cojocaru

\section{Introduction}

1 Many, if not most, people get angry when they disagree, particularly when they disagree about values. Already in Plato, we find the idea that, unlike in cases where evidence is comparatively easy to attain - i.e. when disagreement is about numbers, about magnitudes, or about weight -, disagreement about "the just and unjust, good and evil, honourable and dishonourable" (Plato, Euth.: 7d) is what typically incites "enmity and anger" (ibid.). Questions of value, i.e. questions that are of moral and/or political significance, are precisely the questions that make people disagree vigorously (Midgley 1980: 180). While this view is held through time, there is less agreement about the normative evaluation of such anger. ${ }^{1}$

2 Is it a good, maybe even necessary reaction for a person to get angry when something they value is threatened or destroyed? Or is anger in such situations bad, maybe even irrational? As I will show, both views are defended in the literature and have some plausibility. However, I argue that more can be done about anger than simply evaluating it as is. It can be turned into something of communal value.

Importantly, normative discussions of anger do not subscribe to one theory of emotion. Basic emotion theories (see, e.g. Srinivasan 2018: 15) contrast with evaluative judgment theories (e.g. Nussbaum 2015, 2016); social constructivism is endorsed (see, e.g. Sorial 2017: 122); and the expression of emotion and experience of emotion can come apart (see, e.g. Bommarito 2017: 2; Sorial 2017: 121-2). While this mirrors the diversity within the philosophy of emotion, it inspires me to do something about anger that is more pragmatic, by which I mean: something that is informed by what I think people should want to make of anger rather than by what they, implicitly or explicitly, think that anger essentially is. In what follows, I make explicit the normative commitments of such 
a pragmatic approach to anger and propose to turn anger into passionate disagreement. The pragmatists I am going to draw on are not known experts on anger. However, their views on affectivity (see Hookway 1993, 2003; Trout 2010; Cojocaru 2018) and on community (see Anderson 1997) are central to my interest in the epistemic role of anger.

4 To motivate and anchor my project, I first reconstruct two prominent views of anger through a virtue epistemological lens. I introduce their qualities as well as shortcomings for understanding the epistemic role of anger when people disagree about moral and political values. Next, I develop my own proposal: to turn violent disagreement into one that is passionate. I borrow ideas from pragmatism that preserve the qualities of the views discussed within an interpretative framework that relies on community-oriented sentiments which function as intellectual virtues. These help people regulate their anger to allow for communal problem-solving. I will use an example throughout. I conclude with addressing three worries.

\section{Two Views of Anger in Contemporary Philosophy and their Problems}

5 The contemporary philosophical literature that stands mainly in the Western, analytic tradition nicely reflects the fact that people are in two minds about anger and its role in public life. On the one hand, anger is sometimes seen as good. I call this view "anger as an apt reaction to injustice" 2 because it entails the idea that anger provides people with quick access to moral and/or political beliefs, with no necessary regard to the consequences of acting upon these beliefs. On the other hand, anger is sometimes seen as bad. I call this view "anger as road to perdition in moral and political life" 3 because it entails the idea that anger distorts the formation of beliefs that are the basis for civilised political action, and very much focuses on the consequences.

6 Prima facie, both views are plausible. Now, I am going to reconstruct them by using a virtue epistemological distinction (1.1.) to show that their proponents do not take anger to be the same kind of state. They are talking past each other. I also suggest that these views are epistemically at least problematic, if not vicious (1.2.), though I offer my criticism in a constructive manner. My own proposal builds on the plausible elements of these views while adding both a concern for the varieties of anger and an epistemic community commitment in the spirit of philosophical pragmatism. These need to be heeded before and during the experience of anger if anger is to function well in public life.

\subsection{Anger as a Faculty vs Anger as a Character Trait}

7 Virtue epistemologists are concerned with the virtues needed for acquiring good beliefs. Such virtues can be conceived of as "faculties" or as "character traits" (see Axtell 1997; Turri, Alfano \& Greco 2017). Faculty-virtues are those sources of belief on which we rely as a kind of sensor: we rely on the faculty of eyesight to acquire beliefs about objects around us; accordingly, this conception of virtue is called virtue reliabilism. Alternatively, character trait-virtues are those dispositions we exercise in our efforts to acquire beliefs and for which we can be praised, or for the lack of which we can be reprehended: we are responsible for the conscientiousness or open- 
mindedness and, vice versa, for the sloppiness or narrow-mindedness with which we approach questions; accordingly, this conception of virtue is called virtue responsiblism. ${ }^{4}$

When anger is seen as an "apt reaction to injustice," it is taken to be a faculty, a source of information. On that view, there are facts in the world that "call for" an angry response. Such facts have generally to do with the threat to or destruction of value, more specifically with forms of injustice. The apt recognition of value problems relies on such responses. Not responding angrily to such facts is at best a sign of apathy and at worst due to false consciousness. Now, the question is whether there are such normative facts.

Imagine a park in Sub-Saharan Africa that is a designated area of ecological conservation. One day, we hear that trees in this park have been cut and there are signs that some of the protected animals who live there have been killed. The anger that arises in the community responsible for the park seems a natural response to such destruction of value. Regardless of its metaethical explication, it is a normative fact within that community that nothing that goes contrary to the concept of "ecological conservation" ought to take place in that park. The community has converged on the view that ecological conservation is a or of value, maybe a common good, otherwise the park would not have been so designated.

Just as faculty-virtues enable knowledge, anger enables people to appraise value problems. Indeed, emotional protest and calls for better protection of common goods as well as for public inquiry (see Brady 2016) are an essential part of public life. The view that people who are confronted with threats to or the destruction of value ought to rely on their anger as a faculty to voice their concerns is characteristic of some scholarship in the context of social movements (see, e.g. Lorde 1997 [1981]; Tessman 2005). Importantly, though, the value of an angry response might not lie in its consequences, i.e. whether it is productive, but in its aptness (see Srinivasan 2018: 9). ${ }^{5}$ This view, then, can leave strategic questions unaddressed. ${ }^{6}$ What they eventually achieve to do about them is a different question.

11 This view is supported by the figure of speech "in virtue of." We would understand perfectly well if someone at the scene said: "In virtue of my angry response to the sight of an elephant carcass missing its tusks, I knew that that was wrong!" The person might not exactly know the consequence for her or for the community - having to raise this issue with the authorities or to search for the poachers. However, amidst this normative uncertainty, that much - that that was wrong - is clear in virtue of the anger that serves a faculty. The epistemological view that emotions mimick foundations (see Hookway 1993) dovetails nicely with this idea and adds a pillar to the bridge that leads from the philosophy of emotion into the field of virtue epistemology.

12 At the same time, anger is an admittedly unreliable faculty for at least three reasons. First, while anger makes us attend to certain things, it can also make us fail to attend to the right things because we may be obsessed with the object of our anger (Hookway 2003: 80). Second, our anger might supervene on false beliefs. ${ }^{7}$ Third, a clouded disposition/mood can trigger anger by chance. Therefore, I suggest distinguishing proximate and ultimate objects of anger. If one happens to find the poachers next to the elephant carcass, it seems accurate to think of them or their actions as the proximate object of one's anger. However, if one were to focus one's anger solely on them, one might fail to achieve much, because poaching is a moral problem that entails further 
structural, political issues (Duffy et al. 2019). Venting one's anger at individual poachers is likely to be, at best, superfluous and at worst vicious. ${ }^{8}$

The negative view of anger as "road to perdition in moral and political life" follows from such worries. For those who value human effort, in particular when it comes to one's emotions, the positive view of anger as "apt reaction to injustice" misses the point of what it means to be virtuous in the sense of becoming virtuous through selfcontrol. Instead of quick, hot, retributivist reactions, a level-headed, forward looking approach is advocated. How would that play out in my example?

Let us assume that one hasn't encountered the poachers on site but the news comes in that they have been caught and are far from feeling guilty. They are angry, too, and they contest the idea that ecological conservation is a common good. They claim that what the community has been fencing off as a way of "protecting" the environment is part of their livelihood. ${ }^{9}$ They argue that they have a right to the forest in order to continue their traditional ways of life. ${ }^{10}$ We now have anger facing anger, and another frame of reference is needed in which to evaluate these claims responsibly. While in the grip of anger, such a careful inquiry looks doomed. Accordingly, another philosophical strategy is to acknowledge anger as a sign that something is wrong, but then to quickly transition to cooler emotions. Normal anger ${ }^{11}$ is seen as a problematic way of dealing with information.

Consequently, this view of anger as "road to perdition in moral and political life" conceives of anger mainly in terms of its consequences and these are, in the main, negative. Responding to the threat to or destruction of value angrily is, if at all necessary, ${ }^{12}$ a transitional phase in which one signals (to oneself or others) that something is wrong, and at worst, when continued and systematic, a sign of a deep character flaw. ${ }^{13}$ To return to my example, on this view, anybody upset about what has happened in the park is entitled to feel angry if she must. Maybe the community accepts that anger is deliberately staged and has a particular role to play in politics. However, one should transition into a state of concern for future welfare, justice, or the common good as soon as possible. Unrestrained, normal anger engenders anger, leading to a situation in which hotheads continue to question ever more elements of the normative community consensus, potentially resulting in a threat to the political institutions themselves. This view has received renewed attention in the work of Martha Nussbaum in particular (see Nussbaum 2015, 2016) and is supported by scholars who emphasise political friendship (see Silvermint 2017) and/or deliberative politics (see Sorial 2017).

Through this virtue epistemological lens, it becomes clear that these different philosophers are not talking about the same thing: anger is either a good, reliable faculty or a bad, irresponsible character trait, at least as it occurs in normal human beings ${ }^{14}$ The "road to perdition in moral and political life"-view builds on the idea that humans can regulate their emotions, which makes them profoundly unlike a faculty like seeing or hearing. ${ }^{15}$ The idea of taking responsibility for the development of one's intellectual character is at the heart of virtue responsibilism, which emphasises conscientiousness, open-mindedness, or charity. Generosity, a sense of justice, political friendship, and a commitment to deliberation fit neatly into this list. Anger, then, is not a virtuous character trait, but a vicious one, which needs to be controlled by proper character trait-virtues and its epistemological role is minimal. 


\subsection{Some Shortcomings and Two Problems}

17 Reconstructing part of the debate on anger in virtue epistemological terms suggests that the reason why people are in two minds about it has to do with the fact that they are not talking about the same thing: for some, full blown anger is a faculty, for others, it is a character trait. Two further problems attach to both views because they presuppose what I call the stereotypical view of anger: a phenomenally "hot" state of mind that involves venting, hysteria, threats, and abuses.

Arguably, the man with the red face, leaning across the table, his carotids swollen, raising his voice, is going to disagree with me rather profoundly over the values in question if we are having an argument. Indeed, once we have arrived at the stage of a full blown, violent argument, we are likely too late in the game to make use of the epistemic potential of anger, which is: to offer hypotheses about moral and political values of which other members of one's community might not be aware. However, this only goes to show that philosophical attention is consumed by this stereotypical view and that is problematic for two reasons. First, it involves prejudice about the person who is experiencing anger. Second, it makes us overlook the many faces of anger, i.e. the variations of angry experience that may play critical epistemic roles, going beyond signalling that there is a problem.

Given the stereotype of anger as that force which transforms otherwise sensible people into essentially irrational, retributivist, archaic, blood-thirsty and uncivilised villains (see e.g. Nussbaum 2016: 1-5, chap. 2; 2015), it is easy to suggest that "these people" ought not to be listened to. Angry people have nothing to contribute to value inquiries precisely because they are out of their minds. However, the judgment that people who "look angry" won't be able to deliver any meaningful information or can't be trusted in their judgment is a prejudice, one likely of the kind that the testimony of people of colour cannot be trusted, which Miranda Fricker identifies as "testimonial injustice" (see Fricker 2007). ${ }^{16}$ This is the first problem with the stereotypical view. ${ }^{17}$ This stereotype represents only one possible form of what anger can look like - and only one epistemic function (signalling a problem).

This leads to the second problem. Think of the movie 12 Angry Men, ${ }^{18}$ in which 12 male jurors deliberate the case of an 18-year-old boy accused of murder and who approach the case and the arduous deliberation in very different emotional styles (e.g. deferential and humble, or brash and biased, or stern and analytical). We find the stereotype of anger in the raging businessman and disappointed father who is the last to vote "not guilty" (played by Lee J. Cobb). Now, if the boy was indeed guilty, this behaviour is what defenders of the view of anger as "apt reaction to injustice" would have to find apt, since there is the threat to the value of justice if the boy is acquitted. In contrast, defenders of the view of anger as "road to perdition in moral and political life" would turn away in horror. These two options would be all there is to the role of anger in such a situation of normative uncertainty.

21 However, the movie is called 12 Angry Men and not One Angry Men, Nine Lovers of Justice, and Two Who Just Don't Seem to Really Care. Anger has many faces, to which one needs to pay attention in order to get a full sense of its epistemic potential. There is the cold anger that motivates the inquirer to keep investigating the situation until all the facts are in, fostering perseverance and conscientiousness. There is the anger coupled with incredulity that a particular injustice could at all be true that will motivate the inquirer 
to suspend judgment, fostering healthy scepticism. There is the anger coupled with grief that invites others to finally pay attention to what is going on, fulfilling a communicative role in making the problem accessible to others. ${ }^{19}$ Being aware of these variations helps appreciating states that tend to get dismissed from epistemic business.

Also, simply asking for transition into a concern for future welfare, justice, or the common good is problematic, because precisely these normative notions are not set in stone and, in the situations in which anger occurs, uncertain. To see how, going back to the park example helps. The second display of anger (the one by the poachers) is important and eye-opening: to the problem of green colonialism (see, e.g. Mbaria \& Ogada 2016), to the actual power disparities that can exist underneath any presumed community consensus, and so on. At the same time, the precise contours of the value conflict over the park and its legitimacy are still not clear. While the community seems to disagree, then, over ecological conservation contra traditional ways of life, it is easy to imagine a third group that is already latently angry because its concern is not taken seriously: say the protection of all animals in the park, not just of charismatic species like the elephant. Attempts at settling the situation that would include limited use of the forest will be met by opposition and angry protest by them. It is not difficult to come up with even further parties (or individuals) who take issue with yet other aspects of the situation that had not been accounted for. ${ }^{20}$

What we have in situations of violent disagreement, then, is a chain reaction of anger. In order to evaluate which anger is useful, anger cannot be taken at face value. Not every expression of anger reliably detects a real wrong. People can be even justified in their experience of emotions but still mistaken (see Deonna \& Teroni 2012). The problem does not go away by merely stating that the virtuous anger is the one expressed by the virtuous person who is characterised by the fact that she is committed to already acknowledged values, e.g., to an Aristotelian view of political friendship (see Silvermint 2017), to deliberative democracy (see Sorial 2017), or to specific praiseworthy or virtuous concerns (see e.g. Bommarito 2017). This, arguably, is circular. In contrast, the point is to tap into anger's potential to identify threats to values that are not already acknowledged.

24 I want to stress that people may be right to react angrily to the normative uncertainty in a situation that might, after thorough investigation, yield new political values, constellations, and concerns. After all, and quite in line with the standard pragmatic view of a problematic situation, their habits of going about their world are disturbed, challenged, endangered. The situation is indeterminate in the sense that it is not clear how to go on from here. And problem solving, i.e. an inquiry, must begin. In that sense, then, at least within democratic communities, any anger must be considered a hypothesis as to what the problem is, involving an attitude towards solving the problem. Whether the hypothesis and attitude are sound is open to interpretation and investigation. That way, the complexity value conflicts display can be embraced: communities move from what people, initially, took to be the problem (the missing trees and animals in the park) on to the real problem (the articulation of which needs to account for everyone affected by the normative uncertainty).

Arriving at the complete picture of the value conflict can be stated more technically. Insofar as the respective value is the formal object of the emotion (see Teroni 2007; Deonna \& Teroni 2012), it is important to remain open to the experience of further anger in order to account for everything that affects anyone involved. This has 
important implications for the two extant views. Those who conceive of anger as "apt reaction to injustice" must make explicit how a community can know in advance whose anger features a correct formal object, whose cause is righteous and whose is not, in order to avoid the risk of blind partisanship. Those who conceive of anger as "road to perdition in moral and political life" must realise that one should not try to change the formal object at will (and with it, both the emotion and the subject) because this would be abandoning the epistemic potential of anger. By simply defending the prevailing community standards, one runs the risk of moral smugness: communities might exhibit a lack of emotional understanding that would allow them to assess the situation comprehensively. Also, trusting the institutions too much can stand in the way of improving them. Again, moving towards the love of justice or sense of political friendship that affirms the status quo without hesitation risks not tapping into the critical potential of anger.

\section{Pragmatism, Anger, and Emotions in Inquiry}

I argue that communities can adopt a pragmatic approach to anger in order to make full use of its role in mapping value conflicts. This involves focussing on what one wants to make of anger rather than focussing on what anger essentially is. For pragmatists, anger is an epistemic problem, a problem of misunderstanding. Charles Sanders Peirce said: “'I do not understand you,' is the phrase of an angry man." (Peirce 1992a [1868]: 44). The particular problem about not understanding each other comes out in John Dewey's statement: "To fail to understand is to fail to come into agreement in action; to misunderstand is to set up action at cross purposes." (Dewey 1988 [1925]: 179). Being angry, then, is a problem, because it prevents people from acting together. Since moral and political life depends on people acting together under mutually accepted norms, the breakdown of these shared habits is unsettling. ${ }^{21}$

Pragmatism offers a cognitivist theory of emotion (see, e.g. Savan 1981; Cojocaru 2018) that allows to reign in the unreliable aspects of anger in a way that involves more than just reason as a counterpart. It involves specific other emotional dispositions - namely the sentiments of faith, love, and hope - that function as intellectual virtues. These commit the individual to a particular notion of community, and combine reliabilist and responsibilist elements, which can be harnessed in the regulation of anger. To better understand this, I next explain the role community plays in inquiries, and I introduce the concomitant virtues that are both intellectual and emotional. I then introduce "passionate disagreement" as an alternative to the other two views of anger. Its advantage is that it appreciates the varieties of anger and avoids potential epistemic injustice. A disadvantage is that it broadens the scope of the problem of emotions in public life because it becomes clear that anger cannot be treated in isolation. However, this brings the philosophical analysis and evaluation of anger closer to the realities of moral and political life. For people are rarely, if ever, just angry.

\subsection{Affectivity and Community-Oriented Intellectual Virtues in Inquiry}

A pragmatic intellectual virtue is a habit of cognising and reasoning that entails appropriate actions. It is tied to the pragmatist view of belief as habit of mind, 
involving some action (see Peirce/CP 5.398). E.g. to show open-mindedness is equivalent to having the habit of not jumping to conclusions. These habits combine reliabilist and responsibilist elements because of the different affective states that come into play. ${ }^{22}$

For pragmatists, it is a mark of intellectual virtue to experience the right kind of doubt and to ask the right kind of questions (see Hookway 2008; Peirce/CP 5.370). Equally, it is the defining character trait of the inquirer that her epistemological concerns should not be about herself alone, but that they "must embrace the whole community" (Peirce/CP 2.654). In the acquisition and exercise of intellectual virtues, then, both kinds of affective states are needed. To have the faculty of reliably experiencing real doubt rather than letting oneself be fooled by what Peirce famously called "paper doubts" (Peirce/CP 6.498) is a habit in the sense of a disposition to take some questions or problems seriously and others not, and it accords with the reliabilist emphasis on virtues that are constitutive of knowledge. To have the character trait of having hope in the community of inquiry rather than letting oneself be fooled by epistemic pessimism (see Peirce/CP 1.405) is a habit in the sense of a disposition to persevere in the face of problems and it accords with the responsibilist emphasis on virtues that enable knowledge in the first place.

30 The idea of intellectual virtue hinges on the possibility to distinguish good and bad intellectual habits by looking at their consequences for the community. Good habits are those that provide inquirers with stable, epistemically productive ways of cognising and reasoning. They help tracking the truth (immediately, or in the long run) because of their community commitment. ${ }^{23}$ Indeed, when pragmatists are talking about inquiry, they are talking about community at the same time. Acknowledging the limited resources, chances, and biases an individual inquirer has, one accepts that the individual is the site of potential error (see de Waal 2006). However, when in doubt, i.e. whenever confronted with a problem, one is not entirely left by one's own devices. Rather, people turn to others because one must hope that, in pooling one's efforts, chances are higher that one finds out how things are (see Hacking 1991) and partakes in the growth of reasonableness (Trout 2010: 39-40). Peirce postulated a strong nexus between sociality and logicality, forcing anyone to accept as default position: that anybody else's opinion is "quite as good as his own" (Peirce/CP 5.378) so that "the problem becomes how to fix belief, not in the individual merely, but in the community" (ibid.).

31 Such humble doubtfulness which is of political significance (see Anderson 1997) is fostered by three specific character traits that Peirce called "logical sentiments." Elucidating the nexus between logicality and sociality, Peirce mentioned that a good (in my sense: virtuous) inquirer is characterised by an "interest in an indefinite community, recognition of the possibility of this interest being made supreme, and hope in the unlimited continuance of intellectual activity" (Peirce 1992b [1878]: 150). These are intellectual versions of the (theological) virtues of faith, love, and hope (see Hookway 1993: 166-7). That inquirers are marked by such community commitment is crucial in distinguishing this ideal community from the community forces at play in the other methods of fixing belief that Peirce discusses (authority, a priori). ${ }^{24}$ Applied to the problem of regulating anger, it is important that, ultimately, the anger ought not to be just about the individual self. ${ }^{25}$ 


\subsection{Anger's Future as Passionate Disagreement} both reliabilist elements (detecting valuable questions) and responsibilist elements (regulating inquiry by directing the attention toward the epistemic good of the community). What does that mean for anger? Can angry responses count as valuable sources of information and be indicative of a character that is useful in inquiry? I believe that is the case.

I agree with the two views of anger discussed on the reliabilist point: anger can be an important sign that something is wrong. However, my proposal to turn anger into passionate disagreement is designed to avoid the shortcomings introduced in 1.2.: that a stereotypical view of anger is perpetuated that is eo ipso neither apt nor merely transitional. While I aim to cover a wide range of emotions that are often disqualified from inquiry, ${ }^{26}$ the only qualifying element is that the intentional object of the emotion is not only relevant for just one self. If the distinction between "private" and "public" was not so coarse and hadn't historically cut off a range of concerns that were indeed relevant for the whole community by labelling them as "private," it would make sense to say that the qualifying condition is that there is a public dimension to the issue at hand. Hence, for lack of a better term, I will say that an other-regarding concern is central to the kinds of anger that ought to be used in moral and political inquiries and this otherregarding concern distinguishes what I call passionate disagreement from personal frustration, even if severe. ${ }^{27}$

wen wet angry, what happens, from an epistemological point of view, is that we receive new information. The people who receive the news about what has happened in the park come to know that there is a problem, that things are not running smoothly; some people will know that directly in virtue of their own angry response; others will take the anger of others as indicative of that much.

Often when confronted with another person's anger, we tend to interpret this disagreement in the sense that the person ${ }^{28}$ who is disagreeing with us is contesting what we take as a fact about the values involved: the poachers don't see the environmental value in the forest, but its use value; the animal advocates don't see the animals as resources, but as deserving protection of their lives and liberties. ${ }^{29}$

From a pragmatic perspective, the forest and the animals can be valued in all such ways. However, these values are practically incompatible, and the goal of moral and political inquiries is to find out what ought to be valued. The different perspectives and angry experiences need to be interpreted; they cannot be taken at face value but need to enter communal inquiry as hypotheses that may be accepted or refuted. They need to be transformed in light of the epistemic community commitment. I assume that a pragmatically objective answer to the normative uncertainty at hand, i.e. an answer that holds true for everyone potentially involved, can be found (see Bakhurst 2013; Heney 2016). However, along the way, disagreement of this kind has the potential to become violent. To instead pave the way for passionate disagreement, I offer the following four pragmatic considerations.

The first pragmatic consideration is that there may be reasons for a disagreement turning violent that operate at a meta-level. For instance, one might not trust that all members of the community are trying to find out how things really are. ${ }^{30}$ Not only particular losses of, or threats to, values can create the uncertainty that incites anger,

European Journal of Pragmatism and American Philosophy, XII-2 | 2020 
but also doubts concerning the motives and intellectual virtues of the opponent. ${ }^{31}$ People sometimes doubt their opponents' anger both in terms of reliably pointing to severe wrongs and in terms of being genuine, in the sense that it is regulated by an epistemic community commitment. For example, if the poachers come to assume racism as one of the driving forces behind the efforts to protect the park in the first place, this is likely to further infuriate them. They cannot trust that the community outrage is identifying the values of everyone implicated in the situation. Hence, they cannot trust that it will be used to further inquiry into what is best for the community as a whole. Once there is reason to believe that someone is not intellectually virtuous which means, too, that she is not genuinely expressing her emotions -, serious doubts concerning her epistemic abilities, including her anger, arise.

Another pragmatic consideration is that anger might transcend an existing framework of communal values incorporated by its institutions. Let us assume that the park community also took the risk of adopting an energy technology that can cause severe environmental damage if not properly surveyed, but if properly surveyed, provides comparatively clean and cheap energy. A hazard occurs at the plant. If there is reason to believe that it was solely due to human error or technical failure, getting angry is of little use. However, if it turns out that there was already a lack in conscientiousness with respect to the security issues one would have hoped the community had put in place, anger might be much more useful than a sense of justice: precisely because the institutions did not work in controlling the practice, there is little reason to appeal to them now.

Importantly though, the pragmatic concern for the varieties of anger provides more options to enact anger than the stereotype does. While the "anger as apt reaction to injustice"-view would probably call for angry protests, and the "anger as road to perdition"-view might grant those, but then shush the protesters and insist that community officials do their job, the idea of passionate disagreement allows for different ways in which anger can contribute to the necessary inquiry. There is the cold anger fostering perseverance and conscientiousness that might motivate someone to start proceedings against the company that provided the technology at an international level, a complicated undertaking which requires everything but a hot head. Alternatively, maybe the foreman at the plant experiences incredulous anger fostering healthy scepticism because he feels he knows that everyone has worked according to protocol; he will suspend judgment and go through everything again, potentially detecting that the plant had been deliberately sabotaged. Also, people directly affected by the damage who are struck with more grieving anger fostering communication and accessibility might motivate others to support the inquiry by whatever means (attention, resources, compassion).

Moreover, if people learn to acknowledge more than just the stereotypical anger, something can be done about the fact that anger often seems unproductive. Hence, another pragmatic consideration is that people tend to have views on emotions: the person who gets angry might be the reason for contempt in the person who thinks of herself as sober-minded, and the sobriety in the other may be the reason for even increased anger in the angry person. However, if people subscribe to the idea of passionate disagreement, a non-judgmental attitude to other people's anger is in order, and even a division of emotional labour in situations of value disagreement becomes conceivable. Some people might indeed be better equipped with an anger that is a 
source of information (if potentially alarmist), while others might be better at coolly or grievingly transforming such concerns into public inquiries. To acknowledge and understand such different emotional types rather than dismissing them might enable communities to harness a multitude of perspectives instead of enacting stereotypes. ${ }^{32}$

41 A final pragmatic consideration concerns the tendency to assume that it is typically more or less clear who is entitled to his or her anger (and will be heard) and who is not (and will be shut down). The anger of the disadvantaged tends to be viewed as a legitimate means of socio-political struggle and the anger of the privileged as oppressive. While this may be so in some, maybe even most of the situations, privileging the anger of the disadvantaged nevertheless limits the potential of anger to feature comprehensively in the analysis of the problem. It is precisely the potentially sectarian nature of anger that makes some groups form against others (see Jaspers 2017: 203) and the problem then is that the community commitment shifts. Moreover, the (uncomfortable) possibility is lost that even a privileged person may have reasons to get angry, if only because her perspective has to be part of the problem if she is to be part of the solution.

This brings me back to the distinction between proximate and ultimate objects of anger. Clearly, a privileged donor of the park (maybe even influenced by subconscious racist and/or misanthropist feelings) in her angry reaction to said news constitutes a formidable proximate object of anger. What is needed, though, is an honest, loving, and hopeful inquiry into the mechanisms of such deep frictions in a community. These mechanisms and forces must be seen as the ultimate objects of anger and subject to more lasting efforts than scapegoating one (potentially highly problematic) person. The epistemic community commitment might require that "moral solidarity" be extended even to that privileged person who effectively (if unreflectively) acts as an oppressor (see Harvey 2007: 33-5). Appropriate efforts would allow for forms of disagreement that engage pragmatic, but critical common sense (see Trout 2010, chap.5) and bring underlying misapprehensions to the surface in order to be corrected.

When people disagree violently about moral and political values, stereotypical anger tends to be expressed while "agreeing to disagree" because, presumably, and particularly in this day and age, everyone is entitled to their own values (as expressed in the emotional reactions) and opinions - full stop. Passionate disagreement, in contrast, treats values as something upon which a community must converge. It requires to treat emotions as information that needs to be subject to scrutiny in order to assess it as adequate or inadequate. It transcends the impasse the two other views of anger have arrived at by combining their insights into what anger might be and transforming it into something that can be used.

\section{In Conclusion: Three Potential Problems with Passionate Disagreement}

Maybe we feel we really shouldn't, but many of us get angry when we disagree, particularly when we disagree over moral and political questions. Broadly two views on this fact dominate the contemporary philosophical debate on anger. My goal has been to point to their commonalities, their differences, and their shortcomings from a social-epistemological perspective informed by pragmatism. I have argued that there is reason to believe that anger - understood as that what results from moral and political 
uncertainty and leads to a failure to understand each other and, hence, to a failure to act together - can help understand which values are threatened and to identify the roots of moral and political uncertainty. Therefore, it is neither easy nor advisable to dispel it.

At the same time, taking anger at face value has proven to be potentially unreliable, and treating it as transitional is potentially unjust. In response, I have suggested that communities can regulate and use the variety of angry experiences in situations of moral and political conflict; this I have called "passionate disagreement" and I have elucidated four pragmatic considerations that go along with it. From an epistemological perspective, passionate disagreement combines reliabilist elements (detecting the right questions about value) with responsibilist elements (primarily the commitment to a community of inquirers bound by certain sentiments). From a phenomenological perspective, it avoids the stereotypical view of anger and thus unleashes the full epistemic potential of various kinds of anger, such as the cold anger that fosters perseverance and conscientiousness, the incredulous anger that fosters healthy scepticism, or the grieving anger that fosters communication and accessibility and motivates others to support the inquiry. Passionate disagreement offers a new angle on value conflicts that can lead to considerable normative uncertainty in the public realm; rather than agreeing to disagree, people can engage in meaningful dissent and, in the course of it, might be able to grow as a community. However, readers might see problems with this proposal, three of which I want to raise in concluding.

First, one might wonder whether what I am suggesting here fits what most would still recognise as anger. However, the concern with protecting a particular kind, maybe the stereotypical kind, of anger seems unnecessarily conservative. While there may be no historically and culturally independent "fact of the angry matter," it is a matter of fact that there is a cluster of affective states that originate in moral or political disagreement, and these are characterised by yet another fact, and that is that they tend to be disqualified from epistemic business. Emotion terms do not neatly capture them, and they may include forms of irritation, extreme worrying, grief, despair or hate etc. At present, political and moral inquiries are not successful in dealing with them by just giving them a bad name and excluding those experiences, or by taking them at face value. From a pragmatic perspective, something needs to be done about that. If, in doing so, we end up in a world with no stereotypical anger left, I am not sure that would be a problem.

The second problem involves hardened attitudes. Could it be that people who train their anger as passionate disagreement - who continuously look for and monitor value conflicts to feed them back into the community - will come across as bitter or unforgiving? This is an important worry, and the "anger as apt reaction to injustice"view tends to bite that bullet and accept the existence of "burdened virtues" (see Tessman 2005; for a critical view, see Silvermint 2017). This not entirely undramatic self-understanding can seem odd to some, and I would hope that the focus on community in my account of passionate disagreement helps avoid that the quarrelsome person can self-style herself as a martyr when nobody else shares her cause. However, Peirce did argue that one ought to be unselfish and willing to sacrifice oneself for the good of the community. Could, then, the individual inquirer's peace of mind be a legitimate self-sacrifice? Shall some members of a community be asked to expose 
themselves continuously to the most painful moral and political situations so that they learn to see and report? While this might not always accord well with the demand to be humble, or to be hopeful, I do not think it is entirely unreasonable - lest communities learn to deal with anger in ways that leave everyone all too comfortable with the already known problems, and hence too ignorant.

Finally, the third problem concerns the importance of community. If I place so much emphasis on it, isn't there a risk of conservatism, even of suppression of minorities or particularly progressive individuals? First, any actual community that ignores or suppresses particular experiences of anger that are not just egotistical is clearly acting contrary to the epistemic community commitment. Also, the duty to be critical of oneself and others is a corollary of the virtue epistemological position adopted here. At the same time, an effective change in moral and political views is indeed premised on the whole (or a significant proportion of the) community converging upon new beliefs and establishing new habits of valuing things and acting together. Pragmatists might not have been the first to acknowledge that old habits die hard, but they have taken this very seriously. Hence, not only individual will and insight but also the communal workings of inquiry and the role emotions play in moral and political change have come into focus. If, therefore, my approach to anger in moral and political life is found guilty of some structural conservatism, I can only hope that it will, in the long run, have proven to have erred more often on the side of caution than not. Given the potential of anger to wreak havoc on the moral and political life of communities, caution might not be entirely ill-advised.

\section{BIBLIOGRAPHY}

ANDERSON Douglas R., (1997), “A Political Dimension of Fixing Belief,” in Jacqueline Brunning \& Paul Forster (eds.), The Rule of Reason. The Philosophy of Charles Sanders Peirce, Toronto, University of Toronto Press, 223-40.

ANDERSON Elisabeth, (2012), "Epistemic Justice as Virtue of Social Institutions," Social Epistemology, 26 (2), 163-73. Online: [https://doi.org/10.1080/02691728.2011.652211].

AXTELl Guy, (1997), "Recent Work on Virtue Epistemology," American Philosophical Quarterly, 34 (1), $1-26$.

BAKHURST David, (2013), "Pragmatism and Moral Knowledge," Canadian Journal of Philosophy, 28 (sup. 1), 227-52. Online: [https://doi.org/10.1080/00455091.1998.10717501].

BELL Macalester, (2013), Hard Feelings: The Moral Psychology of Contempt, Oxford, Oxford University Press.

BRADY Michael, (2016), “Group Emotion and Group Understanding," in Michael Brady \& Miranda Fricker (eds.), The Epistemic Life of Groups. Essays in the Epistemology of Collectives, Oxford, Oxford University Press, 95-100. 
BOMMARITO Nicolas, (2017), "Virtuous and Vicious Anger," Journal of Ethics and Social Philosophy, 11 (3), 1-28. Online: [https://doi.org/10.26556/jesp.v11i3.112].

COJOCARU Mara-Daria, (2018), "Passionate Reasoning as Emotional Understanding: Pragmatism and Using Emotions in Inquiry,” Philosophia, 46, 609-24. Online: [https://doi.org/10.1007/ s11406-017-9889-x].

DE WAAL Cornelis, (2006), “Science Beyond the Self: Remarks on Charles S. Peirce's Social Epistemology," Cognitio, 7 (1), 149-63.

DEONNA Julien \& Fabrice TERONI, (2012), The Emotions. A Philosophical Introduction, London, Routledge.

DEWEY John, (1988 [1925]), Experience and Nature, in The Later Works, 1925-1953, ed. by Jo Ann Boydston, Carbondale, Southern University Press.

DIXON Thomas, (2016), "What is Anger? 1. Martha Nussbaum," The History of Emotions Blog. Online: [https://emotionsblog.history.qmul.ac.uk/2016/07/what-is-anger-1-martha-nussbaum/].

DUFFY Rosaleen, MASSÉ Fracis, SMIDT Emile, MARIJNEN Esther, BÜSCHER Bram, VERWEIJEN Judith, RAMUTSINDELA Maano, SIMLAI Trishant, JOANNY Laure \& Elizabeth LUNSTRUM (2019), "Why We Must Question the Militarisation of Conservation," Biological Conservation, 232, 66-72. Online: [https:// doi.org/10.1016/j.biocon.2019.01.013].

FRICKER Miranda, (2007), Epistemic Injustice: Power and the Ethics of Knowing, Oxford, Oxford University Press.

HACKING Ian, (1991), The Taming of Chance, Cambridge, Cambridge University Press.

HARVEY Jean, (2007), "Moral Solidarity and Empathetic Understanding: The Moral Value and Scope of the Relationship," Journal of Social Philosophy, 38 (1), 22-37. Online: [https://doi.org/ 10.1111/j.1467-9833.2007.00364.x].

HENEY Diana B., (2016), Toward a Pragmatist Metaethic, New York, Routledge.

ноокWАY Christopher, (1993), "Mimicking Foundationalism: On Sentiment and Self-Control," The European Journal of Philosophy, 1 (2), 166-7. Online: [https://doi.org/10.1111/j.

1468-0378.1993.tb00030.x].

ноокWАY Christopher, (2003), “Affective States and Epistemic Immediacy," Metaphilosophy, 34 (1/2), 78-96. Online: [https://doi.org/10.1111/1467-9973.00261].

HоокWAY Christopher, (2008), "Questions, Epistemology, and Inquiry," Grazer Philosophische Studien, 77, 1-21. Online: [https://doi.org/10.1163/18756735-90000841].

JASPERS James M., (2017), “Constructing Indignation. Anger Dynamics in Protest Movements," in Rebecca Kingston et al. (eds.), Emotions, Community, and Citizenship. Cross-disciplinary Perspectives, Toronto, Toronto University Press, 201-14.

KAWALL Jason, (2002), “Other-Regarding Epistemic Virtues,” Ratio, 15 (3), 257-275. Online: [https:// doi.org/10.1111/1467-9329.00190].

LORDE Audre, (1997 [1981]), “The Uses of Anger," Women's Studies Quarterly, 25, 278-85. Online: [https://www.jstor.org/stable/40005441].

MBARIA John \& Mordecai OGADA, (2016), The Big Conservation Lie, Auburn/Wa., Lens \& Pens Publishing.

MIDGLEY Mary, (1980), Beast and Man. The Roots of Human Nature, London, Methuen. 
NUSSBAUM Martha, (2015), “Transitional Anger," Journal of the American Philosophical Association, 1, 41-56. Online: [https://doi.org/10.1017/apa.2014.19].

NUSSBAUM Martha, (2016), Anger and Forgiveness. Resentment, Generosity, Justice, Oxford, Oxford University Press.

PEIRCE Charles Sanders, (1931-1958), The Collected Papers of Charles Sanders Peirce, Electronic Edition, reproducing vols. I-VI, ed. by Charles Hartshorne and Paul Weiss (Cambridge/Ma., Harvard University Press, 1931-1935), vols. VII-VIII ed. Arthur W. Burks (Cambridge/Ma., Harvard University Press, 1958).

PEIRCE Charles Sanders, (1992a [1868]), "Some Consequences of Four Incapacities," in The Essential Peirce. Selected Philosophical Writings, volume 1 (1867-1893), edited by Nathan Houser and Christian Kloesel, Bloomington and Indianapolis, Indiana University Press, 28-55.

PEIRCE Charles Sanders, (1992b [1878]), "The Doctrine of Chances," in The Essential Peirce. Selected Philosophical Writings, volume 1 (1867-1893), edited by Nathan Houser and Christian Kloesel, Bloomington and Indianapolis, Indiana University Press, 142-54.

PLATO, (1892), "Euth. Euthyphro," Dialogues of Plato, volume 1, edited and translated by Benjamin Jowett, Cambridge, Cambridge University Press.

RUSSEL James A., (1994), “Is There Universal Recognition of Emotion from Facial Expression? A Review of the Cross-cultural Studies," Psychological Bulletin, 115, 102-41.

SAVAn David, (1981), "Peirce's Semeiotic Theory of Emotion," in Proceedings of the Charles S. Peirce Bicentennial International Congress, Lubbock, Texas Tech Press, 319-33.

SEBO Jeff \& Peter SINGER, (2018), “Activism," in Lori Gruen (ed.), Critical Terms for Animal Studies, Chicago, The University of Chicago Press, 33-45.

SILVERMint Daniel, (2017), "Rage and Virtuous Resistance," The Journal of Political Philosophy, 25 (4), 461-86. Online: [https://doi.org/10.1111/jopp.12121].

SORIAL Sarah, (2017), “The Expression of Anger in the Public Sphere," Journal of Social Philosophy, 48 (2), 121-43. Online: [https://doi.org/10.1111/josp.12188].

SRINIVASAN Amia, (2018), "The Aptness of Anger," The Journal of Political Philosophy, 26 (2), 123-44. Online: [https://doi.org/10.1111/jopp.12130].

TANESINI Alessandra, (2016), “'Calm down dear': Intellectual Arrogance, Silencing and Ignorance,” Aristotelian Society: Supplementary, 90 (1), 71-92.

TESSMAN Lisa, (2005), Burdened Virtues: Virtue Ethics for Liberatory Struggles, Oxford, Oxford Scholarship Online.

TERONI Fabrice, (2007), "Emotions and Formal Objects," Dialectica, 61 (3) (“Affective Intentionality and Practical Rationality”), 395-415. Online: [https://doi.org/10.1111/j.1746-8361.2007.01108.x].

TROUT Lara, (2010), The Politics of Survival. Peirce, Affectivity, and Social Criticism, New York, Fordham University Press.

TURRI John, ALFANO Mark \& John GRECO, (2017), “Virtue Epistemology,” in Edward N. Zalta (ed.), The Stanford Encyclopedia of Philosophy (Summer 2017 Edition). Online: [https://plato.stanford.edu/ archives/sum2017/entries/epistemology-virtue/].

WHITE Patricia, (2012), "Making Political Anger Possible: A Task for Civic Education," Journal of Philosophy of Education, 46 (1), 1-13. Online: [https://doi.org/10.1111/j.1467-9752.2012.00837.x]. 


\section{NOTES}

1. My goal is not to provide or defend a definition of anger with necessary and sufficient physiological and behavioural conditions, supposedly stable through time and across cultures. There is reason to doubt that anger has such a "stable referent" (see Dixon 2016; White 2012; Russell 1994). When I say "anger" I also mean to cover "rage," "wrath," "fury," "indignation," "resentment," "frustration" and other states that may lack an English emotion term, and it may include forms of "irritation," "grief," "despair," or "hate." I am concerned with whatever the emotional reaction to disagreement about values is called.

2. I go into detail below, but I would group the views put forward by Lorde (1997 [1981]), Tessman (2005), or Srinivasan (2018) under this heading. There may be other ways to see anger as good, for instance, when it is seen as "healthy" to "vent" one's feelings. However, I am not interested in them here.

3. Again, I go into detail below, but I would group the views put forward by Nussbaum (2015, 2016), Sorial (2017), or Silvermint (2017) under this heading.

4. While, since 1997, virtue epistemologists have developed views that combine reliabilist and responsibilist elements (see Turri, Alfano \& Greco 2017), I find this distinction still helpful to understand the debate on anger.

5. One might think that only negative consequences are a problem. However, at least Srinivasan (2018: 9) is explicitly rejecting all consequences: "Whether anger is an apt or fitting response to the world does not turn on the consequences, good or bad, of that anger. Apt anger can be counterproductive, making the angry person worse off, and indeed exacerbating the very situation at which she is angry."

6. This is not to say that strategic questions are not addressed. To the contrary, the role of anger is of prime importance to, e.g., the animal rights movement (Sebo \& Singer 2018), and people are, again, in two minds about the question. What I am saying here is that the positive view of anger as an apt reaction to injustice does not require to look towards the consequences of anger.

7. Maybe we have been misled by, e.g. social media and we are now either missing information about the reality or about the intentions of the people who did what angers us.

8. One could be led to make value judgments that are beside the point: everything about these persons, even their feelings of guilt or fear, could be seen as yet another reason for anger. This would be a generalizing form of anger, which borders on contempt. For the view that contempt need not be generalizing, see Bell (2013).

9. Maybe they point to the UN Declaration on the Rights of Indigenous People to make their case.

10. Suppose that ivory poaching has not been part of their way of life previously. However, today, they find themselves in a desperate situation, not least because the community relies on a capitalist economy with insufficient accommodation of their interests. This leaves individuals with little choice, or at least makes it hard for them to resist the temptation of earning an exceptional amount of money through poaching.

11. I take "normal anger" to mean "anger that is not curbed or taken control of." That does not commit me to the view that it will look and feel the same in different people, nor does it commit me to the idea that the same set of action tendencies follows from anger. That would be what I call the "stereotypical view" of anger and I address two of its problems in section 1.2.

12. I am thinking in particular of Nussbaum (2016) here, who conceives of anger as "always normatively problematic" (5), even irrational and stupid (249), and recommends a transition into a concern for the welfare of all, a transition that ideally ought to be sought "soon" $(29,31)$ after a maximally "brief" (31) episode of what she makes out to be the defining element of anger: a wish for payback.

13. Some people are of course more careful than others not to make such judgments of character (see, e.g. Silvermint 2017: 11-2). However, it is not clear to me how one can grant somebody his or 
her genuine political rage while at the same time doubting his or her ability (or nobility) to steer political change.

14. Again, I am thinking of Nussbaum $(2015,2016)$ here, who allows for "a major exception to [her] thesis that anger always involves, conceptually, a thought of payback" (Nussbaum 2016: 35) and that is what she calls "Transition-Anger" (ibid.: 35-40; Nussbaum 2015: 53-4). It involves an immediate jump from the awareness of something outrageous into the concern for welfare and justice, but Nussbaum (2016: 36; verbatim 2015: 54) stresses "how rare and exceptional this pure forward-looking emotion is." I will later assume that this is a much more wide-spread option, given that all emotion involves interpretation.

15. This, again, holds for all emotions, not just for anger, and the notion that we are responsible for doing so, lies at the heart of an understanding of virtue that conceives of them as an effort to strike a balance between certain emotional states: say, of courage as the mean between fear and foolhardiness.

16. This may also be related to the epistemic vice of intellectual arrogance as haughtiness that Alessandra Tanesini describes in Tanesini (2016).

17. Those who conceive of anger as apt reaction to injustice are not at risk of perpetrating such epistemic injustice. For them, these agents are out of their mind - and rightly so. They are agents of social justice, not victims of epistemic injustice. However, phenomenally, anger is understood in precisely the same way. Thus, the view of anger as apt reaction to injustice at least helps to nurture the stereotypical view.

18. I am thinking of the 1957-movie, directed by Sidney Lumet, produced by Henry Fonda and Reginald Rose.

19. For sociological support of this model of mixed emotions, see Jaspers (2017: 208), with references to further literature on how combinations of emotions form "moral batteries." For the view that anger enables communication, see White (2012: 8) and the reference to sociologist Mary Holmes' work.

20. Importantly, not all of the causes will comply with established patterns of what "we" would perceive as prima facie rightful indignation. "We" can imagine a group of senior men and women getting angry about the park situation because young women join different parties to the conflict and, thereby, the public sphere, which they had not been doing in the past. The conflict is politicising a previously unpolitical segment of the population and it is argued, paternalistically, that the young women (possibly: while no doubt able to form a political opinion of their own) will be met with hostility for voicing it, and since, by simply joining one party or another, they are not contributing any new insights, they should rather restrain themselves. "We" can also imagine an outraged white person of European descent who complains that the conflict is hurting her newly established eco-tourism business.

21. Arguably, there is an intricate relation between anger leading to the breakdown of communal habits and anger being a reaction to such breakdown. The people who were disadvantaged by the establishment of the park might have had the legitimate expectation that they would have been consulted prior to the community's decision to establish the park. Let's assume they were ignored. In turn, they might have gotten angry and that anger might have been an additional force that motivated the decision to try poaching. I framed the poaching incident as reason for the normative uncertainty to which the people in the community reacted angrily, because this is when the public first became aware of a value conflict. It might, and possibly should, have been possible for the community to see that earlier, but, pragmatically speaking, this is where they are. Hence, this is where this particular inquiry has to start. The goal is to address the fact that people have lost the stable ground of common sense or shared understanding regarding some of the community's values. Anger is important because of its relation to the threat to and destruction of value. However, as I have argued above, it cannot be taken at face value. It needs to be interpreted. 
22. Calling this an "intellectual virtue" helps to show how pragmatist ideas map onto mainstream epistemology. Moreover, to construe an analogy between habit as virtue in the ethical realm and habit as virtue in the intellectual realm seems justified in light of Peirce's ideas about the relation between the normative sciences, where ethics is prior to logic (broadly conceived, to cover epistemology). Indeed, Peirce holds: "I do aver, and will prove beyond dispute, that in order to reason well, except in a mere mathematical way, it is absolutely necessary to possess, not merely such virtues as intellectual honesty and sincerity and a real love of truth, but the higher moral conceptions." (Peirce/CP 2.82).

23. I should add that this community commitment is precisely not an invitation to what Richard Rorty called "ethnocentricism." Peirce's community is one that is almost paradoxical in that it is precisely not defined against other communities but by the fact that it continually works towards extending its boundaries. He says: "This community, again, must not be limited, but must extend to all races of beings with whom we can come into immediate or mediate intellectual relation. It must reach, however vaguely, beyond this geological epoch, beyond all bonds." (Peirce 1992b/ 1878: 149).

24. Whether Peirce's insistence that "[h] who would not sacrifice his own soul to save the whole world, is [...] illogical in all his inferences collectively" (Peirce 1992b [1878]: 149) is going into the same direction of what later epistemologists have called other-regarding virtues (see e.g. Kawall 2002) is unclear. While on that view, it is essential that others benefit epistemically, for Peirce it is crucial that the community benefits as a whole. On the other hand, presumably, the community can hardly benefit in any other form than through certain individuals benefitting, too.

25. This ensures that the political agenda will not be set by bullies or emotional tyrants.

26. See footnote 1.

27. This is why I don't think that Nussbaum's claim that the idea of "payback" or "retribution" is central to anger (Nussbaum 2016: 21-35) applies in such situations. In cases of value conflict, public anger does not necessarily focus on retribution but may as well focus on restoration or reform. If wishes for these were to count as signs of retributivism, Nussbaum's own focus on future goods would be retributivism in disguise as well. White (2012: $7 \mathrm{f}$.) is also not persuaded by Nussbaum's view. While White, too, offers a distinction between personal, political, and social anger (White 2012: 2-4), her suggestion that what makes political anger political is that political agencies are responsible for what I would call the perceived threat or destruction of values begs the question of what (a) political agency is. It also restricts her discussion to political contexts with a clear institutional set-up; this makes sense for her interest in anger in democracies and democratic civic education. However, I want to cast my net more widely.

28. Metaphorically speaking, not only persons can disagree with us: facts can disagree with our expectations or with each other etc. This is not of my concern here, since, on the side of the facts, there are no affective states involved, although we may find ourselves angered in such a situation.

29. There may be nuances, of course. It may well be that the parties can "see" the value the other party is positing respectively, but that they are not "acknowledging" them as decisive.

30. Another reason may be that the situation is exerting pressure upon the agents because something needs to be done, soon. I neglect this aspect here, because, while being a constraint upon the practical inquiries, it does not strike me as genuinely epistemic.

31. I believe "doubt" captures what is going on better than assuming that we fear the opponent (see Lorde 1997 [1981]: 280-1); while doubt can be accompanied by fear or worries, fear seems too strong.

32. Again, Jaspers agrees concerning political protest when he says: "we need to know far more about the many forms that anger can take, the many ways it can be displayed" (Jaspers 2017: 
209). To mind comes, too, research on emotional communities (Rosenwein) and in the history of emotions generally.

\section{ABSTRACTS}

People can be outraged over, say, mismanagement or fraud and motivated to address such problems; they can, however, also be angry and lash out against the innocent. In addition to such unpredictability, angry people can seem literally out of their mind. My aim is to render anger intelligible and productive from a social epistemological perspective: epistemological because I assume that anger involves value recognition and arouses reflection; social because I assume that the related values and inquiries involve questions of justice and/or morality. I believe that value disagreements are set up at cross purposes if we disqualify the emotional reactions of those whom we judge too unpleasant to understand. However, I also believe that we should not take anger at face value. My proposal is pragmatic for two reasons. First, and in line with classical pragmatist tenets about the role of doubt and other emotions in reasoning, it is pragmatic because I think that anger results from moral and political uncertainty and leads to a failure to understand one another and, hence, to a failure to act together. Second, my proposal is more concerned with what could be made of anger rather than focussing on what anger essentially is. In sum, I suggest that communities can regulate and use the variety of angry experiences in situations of uncertainty and conflict about moral and political values; that would be "passionate disagreement." I explain four pragmatic considerations that go along with it and address three problems one might raise in response.

\section{AUTHOR}

\section{MARA-DARIA COJOCARU}

Hochschule für Philosophie München

mara-daria.cojocaru[at]hfph.de 